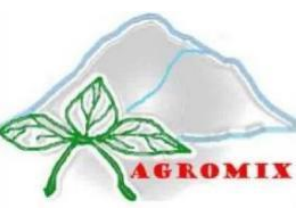

\title{
AGROMIX
}

Jurnal IImiah Fakultas Pertanian, Universitas Yudharta Pasuruan pISSN (Print): 2085-241X; eISSN (Online): 2599-3003

Website: https://jurnal.yudharta.ac.id/v2/index.php/agromix

\section{Fenotipik varietas kedelai pada jarak tanam berbeda yang ditumpangsarikan dengan tanaman jagung}

The phenotypic varieties of soybean at different spacing were intercropped with corn plants

\section{Suyamto ${ }^{1 *}$, Gatut Wahyu Anggoro Susanto ${ }^{1}$, Pratanti Haksiwi Putri ${ }^{1}$}

${ }^{1}$ Balai Penelitian Tanaman Aneka Kacang dan Umbi (Balitkabi), Malang, Jawa Timur

*Email Koresponden: gatut_wahyu2016@yahoo.com

\section{Article History}

Received : July 12, 2020

Accepted : February 04, 2021

Published : March 15, 2021

\section{Keyword}

Intercropped; row spacing;

soybean

\section{ABSTRACT}

The dual system planting aims to utilize existing resources so that they can be more efficient. The research design used separate plots repeated three times. The main plot consisted of soybean spacing of $40 \mathrm{~cm} \times 10 \mathrm{~cm}$ (1 plant per hole) (JT-1), $40 \mathrm{~cm} \times 15 \mathrm{~cm}$ (2 plants per hole) (JT-2) and $40 \mathrm{~cm} \times 20 \mathrm{~cm}$ ( 2 plants per hole). Lubang) (JT-3), a subplot consisting of 11 varieties of soybeans. Soybeans were planted in 3 rows along $5 \mathrm{~m}$ which were intercropped with maize varieties Lamuru $(120-50 \mathrm{~cm}) \times 20 \mathrm{~cm}$ (1 plant/hole) at IP2TP Muneng, Probolinggo Regency, East Java in MK II 2018. The results showed that the varieties "Dena 1" and "Deja 1" matched the intercropping pattern with maize, which were able to achieve seed productivity of $2.17 \mathrm{t} / \mathrm{ha}$ and $2.13 \mathrm{t} / \mathrm{ha}$, respectively. Argomulyo and Anjasmoro varieties in JT-1, Deja 1 on JT-2, and Deja 2 on JT-3 were able to achieve seed productivity of up to $2.0 \mathrm{t} / \mathrm{ha}$. The phenotypic weight of seeds per plant and the number of filled pods were two components that contributed greatly to the increase in seed productivity. Dena 1 varieties correspond to JT1 and JT-2 treatments, while Deja 1 varieties correspond to JT-3 treatments. The phenotypic weight of 100 seeds, plant height, and the number of branches contributed little to the increase in seed productivity.

\section{Riwayat Artikel}

Dikirim : 12 Juli, 2020

Disetujui : 04 Pebruari, 2021

Dipublis : 15 Maret, 2021

\section{Kata Kunci}

Jarak tanam; Kedelai;

Tumpangsari

\section{ABSTRAK}

Penanaman sistem ganda bertujuan untuk memanfaatkan sumber daya yang ada sehingga dapat lebih efisien. Rancangan penelitian menggunakan petak terpisah diulang tiga kali. Petak utama terdiri dari jarak tanam kedelai $40 \mathrm{~cm} \times 10 \mathrm{~cm}$ (1 tanaman per lubang) (JT-1), $40 \mathrm{~cm} \times 15 \mathrm{~cm}$ (2 tanaman per lubang) (JT-2) dan $40 \mathrm{~cm} \times 20 \mathrm{~cm}$ (2 tanaman per lubang) (JT-3), anak petak terdiri dari 11 varietas kedelai. Kedelai ditanam sebanyak 3 baris sepanjang $5 \mathrm{~m}$ yang ditumpangsarikan dengan jagung varietas Lamuru $(120-50 \mathrm{~cm}) \times 20 \mathrm{~cm}$, (1 tanaman/lubang)di IP2TP Muneng, Kabupaten Probolinggo, Jawa Timur pada MK II tahun 2018. Hasil penelitian menunjukkan bahwa varietas Dena 1 dan Deja 1 sesuai pola tumpangsari dengan tanaman jagung yang mampu mencapai produktivitas biji berturut-turut 2,17 tha dan 2,13 tha. Varietas Argomulyo dan Anjasmoro pada perlakuan JT-1, Deja 1 pada JT-2 dan Deja 2 pada JT-3 mampu mencapai produktivitas biji hingga 2,0 t/ha. Fenotipik bobot biji per tanaman dan jumlah polong isi merupakan dua komponen yang berkontribusi besar dalam peningkatan produktivitas bijinya. Varietas Dena 1 sesuai perlakuan JT1 dan JT-2, sedangkan varietas Deja 1 sesuai pada JT-3. Fenotipik bobot 100 biji, tinggi tanaman dan jumlah cabang berkontribusi kecil dalam peningkatan produktivitas bijinya.

Sitasi: Suyamto, S., Susanto, G. W. A., \& Putri, P. H. (2021). Fenotipik varietas kedelai pada jarak tanam berbeda yang ditumpangsarikan dengan tanaman jagung. Agromix, 12(1), 1-6. https://doi.org/10.35891/agx.v12i1.2159

\section{PENDAHULUAN}

Petani di Indonesia pada umumnya memiliki lahan yang sempit, sehingga sangat penting dalam pemanfaatan lahan dan waktu dalam berusaha tani. Karena itu petani berupaya meningkatkan produksi sekaligus meningkatkan pendapatan petani dengan jalan menaikkan intensitas lahan. Penanaman kedelai di antara tanaman jagung atau tumpangsari menciptakan salah satu solusi. Tumpangsari kedelai dan jagung lebih menguntungkan dibandingkan dengan pertanaman tunggal yang memberikan efisiensi dalam pemanfaatan lahan (Yuwariah dkk., 2017; Sari, 2019), efisien secara ekologi dan budidaya tanaman (Lestari dkk., 2019).

Pola tanaman tumpangsari kedelai dengan jagung juga diterapkan di negara Cina, di mana penanaman kembali tanaman jagung berikutnya justru meningkatkan hasil panen, serta mengurangi risiko kegagalan dengan pola tanam 
yang terus menerus (Jun-bo dkk., 2018). Perhitungan nilai rasio kesetaraan lahan pada pola tumpangsari kedelai dengan jagung lebih menguntungkan daripada pola monokultur (Kamara dkk., 2017; Kamara dkk.,2019), karena mengeksploitasi yang lebih tinggi dari sumber daya lingkungan yang terbatas (Kamara dkk., 2019).

Pola tumpangsari tanaman dapat mempengaruhi fenotipik antara lain pada batang tanaman yang lebih panjang, mempercepat umur berbunga dan menurunkan bobot brangkasan kering per tanaman (Chairudin dkk., 2015). Respon fenotipik pada tanaman kedelai terhadap pengaruh naungan berbeda-beda, hal ini tergantung faktor tekanan lingkungannya. Oleh karena itu, penting melakukan penelitian untuk mengkaji tanaman kedelai serta efek fenotipik yang dipengaruhi akibat tekanan lingkungan serta mensiasati teknologi budidayanya untuk menekan penurunan hasil biji tanaman kedelai.

Optimasi cahaya matahari dengan adanya naungan dapat juga dilakukan melalui pengaturan jarak tanam (Wardhana dkk., 2014; Iqbal dkk., 2018). Jarak tanam kedelai yang lebih rapat $(20 \mathrm{~cm} \times 20 \mathrm{~cm})$ meningkat hasil biji sebesar 28,42 \% dibandingkan jarak tanam $20 \mathrm{~cm}$ x $30 \mathrm{~cm}$ (Alim dkk., 2017), berarti jumlah populasi tanaman meningkatkan hasil biji. Untuk itu, diperlukan adanya sistem pengaturan jarak tanam dan populasi tanaman kedelai yang sesuai dalam pola tumpangsari. Tujuan penelitian ini memberikan informasi tentang pertumbuhan (fenotipik) dan hasil biji tanaman kedelai pada jarak tanam yang berbeda yang tumpangsari dengan tanaman jagung.

\section{METODE}

Penelitian dilaksanakan di Instalasi Penelitian dan Pengembangan Teknologi Pertanian (IP2TP) Muneng, Kabupaten Probolinggo, Jawa Timur pada musim kering pertama (MK I) bulan April hingga Juli 2018. Percobaan disusun menggunakan rancangan petak terpisah (Split Plot Design) diulang tiga kali. Perlakuan petak utama adalah jarak tanam (JT) untuk kedelai terdiri dari tiga macam yakni: $40 \mathrm{~cm} \times 10 \mathrm{~cm}$ (1 tanaman per lubang) setara 250.000 tanaman per hektar (JT-1), $40 \mathrm{~cm} \times 15 \mathrm{~cm}$ (2 tanaman per lubang) setara 333.333 tanaman per hektar (JT-2) dan JT-3:40 cm x 20 cm (2 tanaman per lubang) setara 250.000 tanaman per hektar. Perlakuan anak petak terdiri dari 9 varietas kedelai (Argomulyo, Anjasmoro, Dena 1, Deja 1, Deja 2, Dega 1, Detam 2, Detap 1, dan Devon 2), dan dua genotipe (GH K13, dan $\mathrm{GH}$ Kr5). Kedelai ditanam tumpangsari dengan jagung varietas Lamuru, jarak antara tanaman kedelai dengan tanaman jagung sebesar $40 \mathrm{~cm}$, jarak tanam jagung $50 \mathrm{~cm} \times 20 \mathrm{~cm}, 1$ tanaman/lubang. Ukuran petak untuk tanaman kedelai $4 \mathrm{~m}^{2}(5,0 \mathrm{~m} \times 0,8 \mathrm{~m})$ terdiri dari tiga baris, sedangkan untuk tanaman jagung ditanam dalam petak $2,5 \mathrm{~m}^{2}(5,0$ $\mathrm{m} \times 0,5 \mathrm{~m}$ ) sebanyak dua baris.

Penanaman kedelai maupun jagung dilakukan dengan cara tugal, dan dilakukan secara bersamaan. Pupuk yang digunakan adalah Phonska, untuk tanaman kedelai dengan dosis $250 \mathrm{~kg} / \mathrm{ha}$ diberikan seluruhnya bersama tanam, dan untuk tanaman jagung sebanyak $500 \mathrm{~kg} /$ ha diberikan 2 kali aplikasi yakni $50 \%$ bersama tanam dan $50 \%$ pada saat umur 30 hari setelah tanam. Pemeliharaan baik kedelai maupun jagung dilakukan secara intensif, dan penanggulangan gulma maupun hama /penyakit dilakukan sesuai kebutuhan. Pengamatan dan data yang dianalisis hanya pada tanaman kedelai meliputi : tinggi tanaman (cm), jumlah cabang, dan jumlah polong isi, bobot 100 biji (g), hasil biji per tanaman (g), produktivitas biji dalam satuan ton per hektar (t/ha). Nilai produktivitas biji kedelai dan jagung dihitung pada ukuran petak masing-masing dan dikonversikan dalam satuan hektar (ha). Data yang dikumpulkan diuji secara statistik dengan uji F dan jika terdapat beda nyata maka dilanjutkan dengan uji beda nyata terkecil (BNT) taraf $5 \%$.

\section{HASIL DAN PEMBAHASAN}

Hasil analisis varian menunjukkan bahwa perlakuan jarak tanam (petak utama) mengindikasikan mempunyai berpengaruh kuat terhadap 11 varietas/genotipe kedelai yaitu pada bagian tinggi tanaman, jumlah polong isi, dan hasil biji jagung. Perlakuan anak petak (varietas/genotipe) menunjukkan perbedaan nyata antar varietas/genotipe. Perlakuan petak utama (jarak tanam) dengan anak petak (varietas kedelai) pada komponen-komponen tanaman serta hasil biji menunjukkan interaksi nyata pada taraf $5 \%$ (Tabel 1). Hasil interaksi tersebut mengindikasikan perlakukan saling terkait, dan karakter yang terbentuk pada varietas kedelai yang dipengaruhi oleh perlakuan jarak tanamnya. Oleh karena hasil analisis varian menunjukkan interaksi antara petak utama (jarak tanam) dengan anak petak (varietas/genotipe) maka hasil dan pembahasannya menggunakan hasil analisis varian tersebut.

Tabel 1. Hasil analisis varian komponen tanaman dan hasil biji kedelai dan jagung, Probolinggo, MK1 tahun 2018

\begin{tabular}{|c|c|c|c|c|c|c|c|}
\hline \multirow{2}{*}{ Perlakuan } & \multirow{2}{*}{$\begin{array}{l}\text { Tinggi tanaman } \\
(\mathrm{cm})\end{array}$} & \multirow{2}{*}{ Jumlah cabang } & \multirow{2}{*}{ Jumlah polong isi } & \multirow{2}{*}{ Bobot $100 \mathrm{biji}(\mathrm{g})$} & \multirow{2}{*}{$\begin{array}{c}\text { Bobot biji per } \\
\text { tanaman (g) }\end{array}$} & \multicolumn{2}{|c|}{ Produktivitas biji (t/ha) } \\
\hline & & & & & & Kedelai & Jagung \\
\hline \multicolumn{8}{|c|}{ Petak Utama (Jarak tanam) } \\
\hline $\operatorname{Pr}>\mathrm{F}$ & $<, 0001$ & 0,1443 & 0,0357 & 0,1617 & $<, 0001$ & 0,1528 & 0,0235 \\
\hline \multicolumn{8}{|l|}{ Anak Petak (Varietas) } \\
\hline $\operatorname{Pr}>\mathrm{F}$ & $<, 0001$ & $<, 0001$ & $<, 0001$ & $<, 0001$ & $<, 0001$ & $<, 0001$ & 0,0192 \\
\hline \multicolumn{8}{|l|}{ Interaksi } \\
\hline $\mathrm{Pr}>\mathrm{F}$ & $<, 0001$ & $<, 0001$ & $<, 0001$ & $<, 0001$ & $<, 0001$ & $<, 0001$ & \\
\hline
\end{tabular}

Keterangan

$\operatorname{Pr}$ : probabilitas; $\operatorname{Pr}>\mathrm{F}$ : Nilai peluang kesalahan 
Data-data yang disajikan pada Tabel 2 dan 3 merupakan rerata dari pengukuran fenotipik pada perlakuan jarak tanam (JT). Varietas Dena 1 mencapai produktivitas biji tertinggi pada perlakuan JT-2 diikuti JT-1, sedangkan varietas Deja 1 pada perlakuan JT-3. Hal ini menunjukkan bahwa kedua varietas mampu menunjukkan produktivitas biji lebih baik meskipun terjadi interaksi dengan jarak tanam pada kondisi tumpangsari. Selain itu, varietas Argomulyo dan Anjasmoro pada perlakuan JT-1, Deja 1 pada JT-2 dan Deja 2 pada JT-3 mampu mencapai produktivitas biji sebesar $>$ 2,0 t/ha (Tabel 2). Perlakuan pada JT-1, tingkat produktivitas biji varietas Dena 1 sebanding dengan varietas Anjasmoro, sedangkan varietas Anjasmoro sebanding dengan varietas Argomulyo dan Deja 1. Untuk varietas Deja 2 sebanding dengan varietas Dega 1, sedangkan Dega 1 sebanding dengan varietas Devon 2. Selain varietas kedelai tersebut, tingkat produktivitas biji kurang dari 1,5 t/ha. Perlakuan JT-2, varietas Deja 1 dan Deja 2 mampu menunjukkan hasil yang seimbang yaitu sekitar 2,0 t/ha, sedangkan lainnya kurang dari itu, kecuali Dena 1 . Perlakuan JT-3, produktivitas biji Dena 1 dan Deja 2 seimbang yaitu sekitar 2,0 t/ha. Varietas Argomulyo, Anjasmoro, dan Dega 1 maupun GH Gr5 memiliki produktivitas biji kurang dari 1,9 t/ha, bahkan varietas Detam 2, Detap 1, serta genotipe GH K13 dan GH Kr5 kurang dari 1,5 t/ha. Pada ketiga perlakuan jarak tanam varietas Detam 2, Detam 1 dan genotipe GH Gr5 hanya mampu menunjukkan produktivitas biji kurang dari 1,5 t/ha. Berdasarkan tingkat produktivitas bijinya maka Dena 1 menempati rangking pertama, diikuti oleh Deja 1, sehingga Dena 1 sesuai dengan pola tumpang sari pada populasi sekitar 333.300 (perlakuan JT-2). Varietas Deja 1 pada jarak tanam tertentu dan meskipun bukan varietas spesifik untuk tumpangsari dan dalam kondisi naungan menunjukkan potensi hasil biji lebih baik dibandingkan enam varietas lainnya.

Jarak tanam dan jumlah tanaman dalam satu rumpun pada tanaman kedelai akan berimbas pada jumlah populasi tanamannya. Hasil penelitian Egbe (2010) menyatakan bahwa penggunaan populasi tanaman kedelai sejumlah 330.000/ha memiliki produktivitas biji, pertumbuhan tanaman maupun tingkat keuntungan yang lebih baik dibandingkan dengan populasi tanaman kedelai sebesar 400.000 dan 200.000, meskipun menggunakan varietas kedelai yang berbeda. Hasil penelitian lainnya, pada tumpangsari tanaman tebu dengan kedelai yang ditanam dua minggu sebelum tanam tebu dengan jarak tanam kedelai $30 \mathrm{~cm} \times 30 \mathrm{~cm}$ menunjukkan hasil terbaik dibandingkan jarak tanam $20 \mathrm{~cm} \times 20 \mathrm{~cm}$ dan jarak tanam $25 \mathrm{~cm} \times 25 \mathrm{~cm}$ (Rahmasari dkk., 2016), berturut-turut pada populasi tanaman sekitar 222.200, 500.000, dan 320.000. Jumlah populasi tanaman sebanyak $245.000,350.000$, serta 455.00 per ha mempunyai produktivitas biji kedelai yang tidak berbeda (Souza dkk., 2016). Perbedaan hasil penelitian tersebut karena berbeda umur tanaman, karakteristik varietas, jarak tanam, jumlah populasi tanaman serta tanaman tumpangsarinya/naungannya, sehingga dapat berbeda tingkat produktivitas bijinya. Terkait dengan umur tanaman kedelai disinyalir bahwa varietas kedelai berumur genjah (<80 hst), dengan jarak tanam lebih rapat $(20 \mathrm{~cm} \times 20 \mathrm{~cm})$ pada kondisi monokultur menunjukkan hasil biji lebih tinggi dibandingkan dengan kedelai berumur sedang atau panjang seperti Burangrang dan Anjasmoro (Widyaningrum dkk., 2018). Dalam penelitian ini varietas Dena 1 maupun Deja 1 tergolong berumur genjah (berumur $<80$ hari), meskipun mendapat cekaman naungan mampu menunjukkan produktivitas $>2,0 \mathrm{t} / \mathrm{ha}$. Pengaruh lingkungan dengan bentuk tumpangsari dengan jagung berpengaruh kuat terhadap produktivitas biji kedelai hingga menurunkan potensi hasil bijinya, seperti varietas Detam 2, Detap 1, genotipe GH k13, dan Gh Gr5 yang hanya mencapai hasil <1,5 t/ha dibandingkan potensi hasil bijinya $>2,0 \mathrm{t} / \mathrm{ha}$. Varietas kedelai yang tidak terpengaruh kuat perlakuan jarak tanam yang terkait dengan jumlah populasi tanaman pada kondisi tumpangsari masih mampu menunjukkan potensi hasil hingga mencapai > 2,5 t/ha, dan sebaliknya.

Pencapaian produktivitas biji dikontribusi oleh fenotipik komponen-komponen tanamannya. Bobot biji per tanaman berbeda antar jarak tanam dan berinteraksi (Tabel 1), hal ini menunjukkan bahwa model jarak tanam (JT) berpengaruh terhadap bobot biji per tanaman. Varietas Dena 1 memiliki bobot biji per tanaman tertinggi di perlakuan JT-1 dan JT-2 dibandingkan varietas/genotipe lainnya, meskipun jumlah tanaman per lubang/rumpun berbeda (Tabel 2). Hasil penelitian Tirta dkk. (2017) menyatakan bahwa terdapat kecenderungan jumlah tanaman kedelai dalam satu lubang semakin banyak menjadi semakin rendah bobot biji per tanamannya. Bobot biji per tanaman pada perlakuan JT-1 varietas Dena 1 menduduki rangking pertama, selanjutnya diikuti varietas Argomulyo, Deja 1 dan Deja 2. Adapun varietas Detam 2 dan genotipe GH Gr5 menduduki rangking bawah. Pada perlakuan JT-2 varietas Dena 1 menduduki rangking pertama, diikuti oleh Anjasmoro, Deja 1 dan Deja 2, sedangkan rangking bawah diduduki oleh Detam 2, devon 1, GH K13 dan GH Kr5 yang serupa pada perlakuan JT-1. Varietas Devon 2 pada perlakuan JT-1 dan JT-2 tetapi jarak tanam yang lebih lebar (perlakuan JT-3) memiliki bobot biji per tanaman lebih tinggi, tetapi masih sebanding dengan varietas Dena 1, Anjasmoro, Deja 1, dan Deja 2 (Tabel 2). Perolehan bobot biji per tanaman varietas Devon 2 pada perlakuan JT-3 sejalan dengan produktivitas bijinya yang sebanding dengan varietas Dena 1 dan Deja 1 . Bobot biji per tanaman merupakan indikator potensi hasil biji tanaman kedelai dengan kondisi yang optimal untuk pertumbuhan tanaman kedelai.

Bobot 100 biji yang identik kriteria ukuran biji, rata-rata tergolong berukuran biji besar (> $14 \mathrm{~g} / 100$ biji). Varietas Devon 2 mempunyai ukuran biji terbesar pada perlakuan JT-3 mencapai 17,31 g/100 biji. Ukuran biji yang besar pada varietas Devon 2 di perlakuan JT-3 serta kontribusi dari bobot biji per tanamannya mampu memperoleh produktivitas biji menyaingi varietas Dena 1 dan Deja 1 (Tabel 2). Di sisi lainnya, varietas Detap 1 pada perlakuan JT-2 meskipun mempunyai ukuran biji besar tetapi jumlah polong tergolong sedikit, sehingga tingkat potensi hasil biji tergolong rendah (1,33 t/ha). Ukuran bobot 100 biji tidak berpengaruh pada kondisi naungan (Chairudin, dkk., 2015), meskipun 
demikian tingkat produktivitas biji menurun. Di antara varietas kedelai yang konsisten mempunyai ukuran biji besar pada jarak tanam berbeda adalah Anjasmoro, Dega 1 dan Detam 2 (Tabel 2). Besar kemungkinan pengaruh genetik menentukan fenotipik tersebut.

Produktivitas biji jagung berbeda antar jarak tanam kedelai, dan semakin rapat jarak tanam kedelai hasil biji jagung cenderung semakin menurun (Tabel 2). Hal ini menunjukkan bahwa semakin rapat jarak tanam tanaman kedelai terdapat kompetisi antar tanaman yang mempengaruhi produktivitas biji jagung. Berbeda dengan produktivitas biji kedelai, dengan jarak tanam jagung tidak terdapat pengaruh yang nyata. Produktivitas biji jagung yang ditumpangsarikan antar varietas kedelai relatif sama yaitu pada JT-1, JT-2, maupun JT-3. Terdapat kecenderungan tanaman yang berbatang lebih pendek produktivitas biji jagung relatif tinggi. Diprediksi perbedaan tersebut karena pengaruh vegetasi tanaman kedelai, seperti varietas Dena 1, Deja 2 maupun Anjasmoro mempunyai batang tanaman relatif lebih tinggi dibandingkan dengan Dega 1, Devon 2 dan GH Gr3 yang relatif pendek.

Tabel 2. Potensi biji kedelai tumpangsari dengan jagung pada masing-masing jarak tanam, Probolinggo, MK1 tahun 2018

\begin{tabular}{|c|c|c|c|c|c|c|c|c|c|c|c|c|}
\hline \multirow{3}{*}{$\begin{array}{c}\text { Nama } \\
\text { Varietas }\end{array}$} & \multirow{2}{*}{\multicolumn{3}{|c|}{ Bobot $100 \mathrm{biji}$ (g) }} & \multirow{2}{*}{\multicolumn{3}{|c|}{ Bobot biji per tanaman (g) }} & \multicolumn{6}{|c|}{ Produktivitas biji (t/ha) } \\
\hline & & & & & & & \multicolumn{3}{|c|}{ Kedelai } & \multicolumn{3}{|c|}{ Jagung } \\
\hline & JT-1 & JT-2 & JT-3 & JT-1 & JT-2 & JT-3 & JT-1 & JT-2 & JT-3 & JT-1 & JT-2 & JT-3 \\
\hline $\operatorname{Pr}>\mathrm{F}$ & $<0,001$ & $<0,001$ & $<0,001$ & $<0,001$ & $<0,001$ & $<0,001$ & $<0,001$ & $<0,001$ & $<0,001$ & 0.2039 & 0.0246 & 0.2763 \\
\hline Argomulyo & $15.51 \mathrm{a}$ & $12.6 \mathrm{f}$ & $14.62 \mathrm{~d}$ & $13.32 b$ & $12.12 \mathrm{c}$ & $12.07 c$ & $2 \mathrm{~b}$ & $1.69 \mathrm{~cd}$ & $1.89 \mathrm{c}$ & $3.2 \mathrm{ab}$ & $3.2 \mathrm{ab}$ & $3.07 a b c$ \\
\hline Anjasmoro & $14.23 d$ & $14.6 \mathrm{c}$ & $15.55 c$ & $10.98 c$ & $15.04 b$ & $14.21 \mathrm{ab}$ & $2.05 a b$ & $1.75 \mathrm{c}$ & $1.64 \mathrm{~d}$ & $2.5 \mathrm{bc}$ & $2.4 \mathrm{~d}$ & $3.07 \mathrm{abc}$ \\
\hline Dena 1 & $15.07 b$ & $13.5 \mathrm{e}$ & $13.4 \mathrm{e}$ & $14.85 \mathrm{a}$ & 17 a & $13.59 \mathrm{ab}$ & $2.15 \mathrm{a}$ & $2.31 \mathrm{a}$ & $2.06 \mathrm{~b}$ & $3.2 \mathrm{ab}$ & $2.53 \mathrm{~cd}$ & $3.13 \mathrm{abc}$ \\
\hline Deja 1 & $14.39 \mathrm{~d}$ & $15.4 \mathrm{~b}$ & $13.22 \mathrm{e}$ & $13.13 b$ & $14.97 b$ & $14.43 \mathrm{ab}$ & $1.98 \mathrm{~b}$ & $2.08 \mathrm{~b}$ & $2.32 \mathrm{a}$ & $2.73 a b c$ & $3.53 \mathrm{a}$ & $2.87 \mathrm{bc}$ \\
\hline Deja 2 & $15.71 \mathrm{a}$ & $14.5 \mathrm{~cd}$ & $13.07 \mathrm{e}$ & $13.33 b$ & $14.58 b$ & $13.45 b$ & $1.8 \mathrm{c}$ & $1.98 \mathrm{~b}$ & $2.01 b c$ & $2.4 \mathrm{c}$ & $3 \mathrm{abcd}$ & $2.93 \mathrm{abc}$ \\
\hline Dega 1 & $15.17 \mathrm{ab}$ & $14.5 \mathrm{~cd}$ & $14.71 \mathrm{~d}$ & $9.34 \mathrm{~d}$ & $12.47 c$ & $9.54 \mathrm{de}$ & $1.77 \mathrm{~cd}$ & $1.65 \mathrm{~cd}$ & $1.59 \mathrm{~d}$ & $3.33 \mathrm{a}$ & $3 \mathrm{abcd}$ & $3.33 \mathrm{ab}$ \\
\hline Detam 2 & $14.54 \mathrm{~cd}$ & $14.2 \mathrm{~d}$ & $14.76 \mathrm{~d}$ & 7.72 ef & $9.23 d$ & $9.75 d$ & $1.16 \mathrm{~g}$ & $1.43 \mathrm{e}$ & $1.35 \mathrm{e}$ & $2.87 \mathrm{abc}$ & $2.93 \mathrm{abcd}$ & $2.73 c$ \\
\hline Detap 1 & $13.18 f$ & $16.4 \mathrm{a}$ & $16.63 b$ & $11.39 c$ & $12.08 \mathrm{c}$ & $8.44 \mathrm{e}$ & $1.39 \mathrm{e}$ & $1.48 \mathrm{e}$ & $1.13 \mathrm{f}$ & $2.8 a b c$ & $2.6 \mathrm{bcd}$ & $3.27 a b c$ \\
\hline Devon 2 & $12.68 \mathrm{~g}$ & $13.5 \mathrm{e}$ & $17.31 \mathrm{a}$ & $10.79 c$ & $8.68 d$ & $14.64 \mathrm{a}$ & $1.66 \mathrm{~d}$ & $1.48 \mathrm{e}$ & $2.09 \mathrm{~b}$ & $3.13 a b c$ & $3.47 \mathrm{a}$ & $3.33 a b$ \\
\hline GH K13 & $14.71 \mathrm{c}$ & $14.6 \mathrm{c}$ & $13.38 \mathrm{e}$ & $7.24 \mathrm{f}$ & $8.78 d$ & $6.02 \mathrm{f}$ & 1.38 ef & $1.17 f$ & $1.02 \mathrm{f}$ & $2.6 a b c$ & $3.13 \mathrm{abc}$ & $3.1 \mathrm{abc}$ \\
\hline GH Gr5 & $13.67 \mathrm{e}$ & $14.6 \mathrm{~cd}$ & $13.26 \mathrm{e}$ & $8.83 \mathrm{de}$ & $9.42 \mathrm{~d}$ & $9.76 \mathrm{~d}$ & $1.25 \mathrm{fg}$ & $1.64 \mathrm{~d}$ & $1.17 \mathrm{f}$ & $2.73 a b c$ & $3.07 \mathrm{abc}$ & $3.47 a$ \\
\hline Nilai BNT & 0.315 & 0.42 & 0.634 & 1.146 & 1.141 & 1.119 & 0.137 & 0.108 & 0.156 & 0.747 & 0.639 & 0.563 \\
\hline
\end{tabular}

Keterangan

$\operatorname{Pr}$ : probabilitas; $\operatorname{Pr}>\mathrm{F}$ : Nilai peluang kesalahan

JT-1 : $40 \mathrm{~cm} \times 10 \mathrm{~cm}$ (1 tanaman per lubang)= 250.000 tanaman per hektar

JT-2 : $40 \mathrm{~cm} \times 15 \mathrm{~cm}$ ( 2 tanaman per lubang)= 333.333 tanaman per hektar

JT-3 : $40 \mathrm{~cm} \times 20 \mathrm{~cm}$ ( 2 tanaman per lubang)= 250.000 tanaman per hektar

angka yang diikuti oleh huruf yang sama menunjukan tidak berbeda nyata pada taraf $5 \%$

Jumlah polong isi yang terbentuk berbeda antar jarak tanam, antar varietasnya serta berinteraksinya kuat (Tabel 3). Perlakuan JT-3 rata-rata memiliki jumlah polong lebih banyak meskipun selisih dengan perlakuan JT-2 tidak nyata, tetapi berbeda dibandingkan dengan perlakuan JT-1. Perlakuan jarak tanam yang lebih renggang (JT-2) cenderung meningkatkan jumlah polong. Varietas Dena 1 dan Deja 1 memiliki jumlah polong terbanyak di antara materi yang diuji bersamanya dan sejalan dengan tingkat produktivitas bijinya. Varietas Dena 1 pada perlakuan JT-2 menunjukkan jumlah polong isi terbanyak, yang dikontribusi oleh bobot biji per tanamannya hal ini yang mengakibatkan varietas Dena 1 memiliki produktivitas biji lebih tinggi di bandingkan dengan lainnya. Varietas Deja 1 memiliki jumlah polong terbanyak (41 polong) pada perlakuan JT-1 dan 44 polong pada perlakuan JT-3, yang selaras dengan tingkat produktivitas bijinya. Genotipe GH K13 maupun GH Gr5 pada ketiga perlakuan jarak tanam relatif memiliki fenotipik jumlah polong isi terendang di bandingkan varietas lainnya, hal inilah yang mengakibatkan tingkat produktivitas biji kalah dengan lainnya.

Meskipun fenotipik jumlah cabang dengan jarak tanam berinteraksi, paling banyak hanya 3 cabang dengan ratarata dua cabang (Tabel 3). Jumlah cabang yang tumbuh pada batang utama relatif sama di antara model jarak tanam, tetapi antar varietas berbeda nyata. Cabang pada tanaman kedelai yang diuji tidak sejalan dengan tingkat produktivitasnya, hal ini menunjukkan bahwa peran jumlah cabang relatif rendah. Cabang pada tanaman kedelai akan bertambah banyak jika ditanam dengan jarak tanam yang semakin lebar. Jarak tanam $40 \mathrm{~cm} \times 20 \mathrm{~cm}$ ini belum menunjukkan jumlah cabang yang lebih dari empat buah.

Fenotipik tinggi tanaman kedelai antar jarak tanam dan varietas berbeda dan berinteraksi (Tabel 3). Perlakuan jarak tanam rapat (JT-1) cenderung menunjukkan tanaman lebih tinggi (pemanjangan batang tanaman). Varietas Detam 2 memiliki fenotipik batang tanaman yang lebih tinggi pada perlakuan JT-1 dan JT-3 dibandingkan lainnya. Peningkatan tinggi tanaman tersebut sebagai akibat adanya pemanjangan ruas batang (Paciullo dkk., 2011; Yamazaki dkk., 2018), yang merupakan penghindaran akibat kekurangan intensitas cahaya matahari (Franklin, 2008). Varietas Dena 1 dan Deja 1 juga memiliki fenotipik batang tanaman tergolong tinggi, namun ruas-ruas yang terbentuk memiliki jumlah polong lebih banyak di bandingkan dengan Detam 2. Pemanjangan batang tanaman dapat juga disebabkan oleh jarak tanam yang rapat (Yamazaki dkk., 2018), serta naungan tanaman lainnya (Wu dkk., 2017) termasuk oleh 
tanaman jagung. Hasil penelitian lain dengan menggunakan jarak tanam tergolong rapat, yaitu $25 \mathrm{~cm} \times 25 \mathrm{~cm}, 15 \mathrm{~cm} \times$ $15 \mathrm{~cm} \times 40 \mathrm{~cm}$, dan $20 \mathrm{~cm} \times 20 \mathrm{~cm} \times 40 \mathrm{~cm}$ tidak menunjukkan pengaruh yang nyata terhadap pemanjangan batang (Irwan dkk., 2019). Namun demikian, perlakuan jarak tanam terhadap fenotipik tinggi tanaman tidak konsisten pada perlakuan JT1, JT-2 dan JT-3. Di antara kedelai yang diuji pada model tumpangsari dengan jagung bahwa batang tanaman varietas Argomulyo dan GH Gr5 relatif terendah. Tinggi tanaman merupakan komponen yang merespon terhadap kekurangan cahaya yaitu perpanjangan pada ruas-ruas batang. Hasil pengukuran tanaman contoh pada setiap varietas menunjukkan penambahan panjang pada batang. Oleh karena itu, naungan pada tanaman kedelai mempunyai pengaruh besar terhadap pemanjangan batang (Permanasari \& Kastono, 2012).

Berdasarkan penelitian-penelitian tanaman kedelai tentang jarak tanam maupun tumpangsari memberikan hasil yang berbeda. Perbedaan terletak pada tingkat naungan tanaman tumpangsari maupun jenis tanaman, model jarak tanam, serta jumlah populasi tanaman kedelainya. Untuk itu, hasil penelitian ini yang utama menekankan penggunaan varietas Dena 1 dengan model jarak tanam JT-1, JT-2 maupun JT-3 dan dapat memanfaatkan varietas Deja 1 dengan menggunakan model jarak tanam JT-3 pada tumpangsari tanaman jagung.

Tabel 3. Fenotipik tanaman kedelai tumpangsari dengan jagung pada masing-masing jarak tanam, Probolinggo, MK1 tahun 2018

\begin{tabular}{|c|c|c|c|c|c|c|c|c|c|c|c|c|c|c|c|c|c|c|}
\hline \multirow{2}{*}{$\begin{array}{c}\text { Nama } \\
\text { Varietas } \\
\text { Perlakuan }\end{array}$} & \multicolumn{6}{|c|}{ Tinggi tanaman $(\mathrm{cm})$} & \multicolumn{6}{|c|}{ Jumlah cabang } & \multicolumn{6}{|c|}{ Jumlah polong isi } \\
\hline & \multicolumn{2}{|c|}{ JT-1 } & \multicolumn{2}{|c|}{$\mathrm{JT}-2$} & \multicolumn{2}{|c|}{$\mathrm{JT}-3$} & \multicolumn{2}{|c|}{$\mathrm{JT}-1$} & \multicolumn{2}{|c|}{ JT-2 } & \multicolumn{2}{|c|}{$\mathrm{JT}-3$} & \multicolumn{2}{|c|}{ JT-1 } & \multicolumn{2}{|c|}{$\mathrm{JT}-2$} & \multicolumn{2}{|c|}{ JT-3 } \\
\hline $\mathrm{Pr}>\mathrm{F}$ & \multicolumn{2}{|c|}{$<0,001$} & \multicolumn{2}{|c|}{$<0,001$} & \multicolumn{2}{|c|}{$<0,001$} & \multicolumn{2}{|c|}{$<0,001$} & \multicolumn{2}{|c|}{0,0018} & \multicolumn{2}{|c|}{0,0044} & \multicolumn{2}{|c|}{$<0,001$} & \multicolumn{2}{|c|}{$<0,001$} & \multicolumn{2}{|c|}{$<0,001$} \\
\hline Argomulyo & 70,7 & $f$ & 58,3 & $\mathrm{e}$ & 57,3 & $f$ & 2 & cde & 2 & $\mathrm{bc}$ & 3 & $a b$ & 37 & $a b$ & 28 & de & 33 & de \\
\hline Anjasmoro & 98,3 & $\mathrm{~cd}$ & 101,0 & $a b$ & 93,3 & c & 3 & $a b c$ & 3 & $a b$ & 2 & $\mathrm{~cd}$ & 36 & $\mathrm{bc}$ & 30 & de & 35 & cde \\
\hline Dena 1 & 104,3 & bc & 82,3 & cd & 94,3 & c & 2 & de & 2 & bc & 2 & bc & 36 & bc & 48 & a & 40 & $a b$ \\
\hline Deja 1 & 109,0 & b & 93,7 & abc & 84,3 & d & 2 & bcd & 2 & cd & 3 & $a b$ & 41 & $\mathbf{a}$ & 36 & bc & 44 & a \\
\hline Deja 2 & 91,7 & $d$ & 63,0 & $\mathrm{e}$ & 81,0 & $d$ & 3 & $a b$ & 2 & $\mathrm{~cd}$ & 2 & bc & 35 & bc & 36 & $\mathrm{bc}$ & 39 & $a b c$ \\
\hline Dega 1 & 73,7 & $f$ & 102,7 & $a$ & 51,3 & g & 1 & $\mathrm{e}$ & 1 & $\mathrm{~cd}$ & 1 & d & 25 & ef & 38 & $b$ & 24 & $f$ \\
\hline Detam 2 & 119,0 & $a$ & 89,7 & $\mathrm{~cd}$ & 122,0 & a & 2 & bcd & 2 & $\mathrm{bc}$ & 3 & $a b c$ & 23 & ef & 28 & de & 33 & de \\
\hline Detap 1 & 84,3 & $\mathrm{e}$ & 92,0 & bcd & 73,3 & $\mathrm{e}$ & 3 & $a$ & 3 & $a$ & 2 & bc & 28 & de & 32 & $\mathrm{~cd}$ & 23 & $\mathrm{fg}$ \\
\hline Devon 2 & 67,0 & $f$ & 96,3 & $a b c$ & 74,7 & e & 2 & de & 1 & $d$ & 3 & $\mathrm{a}$ & 31 & $\mathrm{~cd}$ & 26 & $\mathrm{e}$ & 37 & bcd \\
\hline GH K13 & 98,0 & $\mathrm{~cd}$ & 55,7 & $\mathrm{e}$ & 99,3 & $b$ & 0 & $f$ & 1 & $d$ & 1 & $d$ & 22 & $f$ & 26 & e & 18 & $\mathrm{~g}$ \\
\hline GH Gr5 & 58,3 & $\mathrm{~g}$ & 65,0 & $d$ & 60,0 & $f$ & 3 & $a$ & 3 & $a b$ & 2 & $\mathrm{~cd}$ & 25 & ef & 26 & $\mathrm{e}$ & 30 & e \\
\hline Nilai BNT & 6,9266 & & 10,4920 & & 4,8700 & & 0,8 & & 0,9 & & & 553 & 5,08 & & 4,70 & & 5,3244 & \\
\hline
\end{tabular}

Keterangan

$\operatorname{Pr}$ : probabilitas; $\operatorname{Pr}>\mathrm{F}$ : Nilai peluang kesalahan

JT-1 : $40 \mathrm{~cm} \times 10 \mathrm{~cm}$ (1 tanaman per lubang)= 250.000 tanaman per hektar

JT-2: $40 \mathrm{~cm} \times 15 \mathrm{~cm}$ (2 tanaman per lubang)= 333.333 tanaman per hektar

JT-3 : $40 \mathrm{~cm} \times 20 \mathrm{~cm}$ ( 2 tanaman per lubang)= 250.000 tanaman per hektar

angka yang diikuti oleh huruf yang sama menunjukkan tidak berbeda nyata pada taraf $5 \%$

\section{KESIMPULAN}

Varietas Dena 1 sesuai untuk pola tumpangsari dengan tanaman jagung dengan populasi tanaman lebih padat (JT2) dan Deja 1 populasi tanaman agak jarang (JT-3). Varietas Dena 1 yang di tanam jarak $40 \mathrm{~cm} \times 10 \mathrm{~cm}$ (JT-1) dan 40 $\mathrm{cm} \times 15 \mathrm{~cm}$ (JT-2) yang ditumpangsarikan dengan tanaman jagung mencapai produktivitas biji berturut-turut 2,15 t/ha dan 2,31 t/ha yang dikontribusi oleh fenotipik bobot biji per tanaman (14,85 g - 14,84 g) dan 36 hingga 48 jumlah polong isi. Varietas Deja 1 yang di tanam jarak $40 \mathrm{~cm}$ x $20 \mathrm{~cm}$ (JT-3) yang ditumpangsarikan dengan tanaman jagung mencapai produktivitas biji 2,32 t/ha, dengan dikontribusi oleh fenotipik bobot biji per tanaman sebesar 13,59 g dan 44 polong isinya. Varietas Argomulyo dan Anjasmoro pada perlakuan JT-1, Deja 1 pada perlakuan JT-2 dan Deja 2 pada perlakuan JT-3 mampu mencapai hasil biji 2,0 t/ha, yang dikontribusi oleh komponen fenotipik yang ditumpangsarikan dengan tanaman jagung mencapai produktivitas biji serta jumlah polong isinya. Fenotipik bobot 100 biji, tinggi tanaman dan jumlah cabang berkontribusi kecil dalam peningkatan produktivitas bijinya.

\section{UCAPAN TERIMA KASIH}

Pada kesempatan ini kami menyampaikan ucapkan banyak terima kasih kepada Sdr. Sugianto B. Selaku staf Teknik KP. Muneng-Probolinggo, yang telah membantu selama kegiatan penelitian di lapangan.

\section{DAFTAR PUSTAKA}

Alim, A. S., Sumarni, T., \& Sudiarso, S. (2017). Pengaruh jarak tanam dan defoliasi daun pada pertumbuhan dan hasil tanaman kedelai (Glycine max L.). Jurnal Produksi Tanaman, 5 (2), 273-280.

Chairudin, C., Efendi, E., \& Sabaruddin, S. (2015). Dampak naungan terhadap perubahan karakter agronomi dan morfo-fisiologi daun pada tanaman kedelai (Glycine max (L.) Merrill). Jurnal Floratek 10(1),26-35. 
Egbe, O. M. (2010). Effects of plant density of intercropped soybean with tall sorghum on competitive ability of soybean and economic yield at Otobi, Benue State, Nigeria. Journal of Cereals and Oilseeds, 1(1),1-10.

Franklin, K. A. (2008). Shade avoidance. New Phytol, 179(4), 930-944. https://doi.org/10.1111/j.14698137.2008.02507.x

Iqbal, N., Hussain, S., Ahmed, Z., Yang, F., Wang, X., Liu, W., Yong, T., Du, J., Shu, K., Yang, W., \& Liu, J. (2019). Comparative analysis of maize-soybean strip intercropping systems: a review. Plant Production Science, 22 (2), 131-142. https://doi.org/10.1080/1343943X.2018.1541137

Irwan, A. W., Wahyudin, A., \& Sunarto, T. (2019). Respons kedelai akibat jarak tanam dan konsentrasi giberelin pada tanah inceptisol Jatinangor. Jurnal Kultivasi, 18 (2), 924-932. https://doi.org/10.24198/kultivasi.v18i2.22232

Jun-bo, D., Tian-fu, H., Jun-yi, G., Tai-wen, Y., Xin, S., Xiao-chun, W., Feng, Y., Jiang, L., Kai, S., Wei-guo, L., \& Wen-yu, Y. (2018). Maize-soybean strip intercropping: Achieved a balance between high productivity and sustainability. Journal of Integrative Agriculture, 17(4), 747-754. hthttps://doi.org/10.1016/S2095-3119(17)61789-1

Kamara, A. Y., Tofa, A. I., Ademulegun, T., Solomon, R., Shehu, H., Kamai, N., \&Omoigui, L. (2019). Maize-soybean intercropping for sustainable intensification of cereal-legume cropping systems In Northern Nigeria. Experimental Agriculture, 55(1), 73-87. https://doi.org/10.1017/S0014479717000564

Lestari, D., Turmudi, E., \& Suryati, D. (2019). Efisiensi pemanfaatan lahan pada sistem tumpangsari dengan berbagai jarak tanam jagung dan varietas kacang hijau. Jurnal Ilmu-Ilmu Pertanian Indonesia, 21(2), 82-90. https://doi.org/10.31186/jipi.21.2.82-90

Paciullo D. S. C., Fernandes, P. B., de Miranda_Gomide C. A., C.R.T. de Castro, de Souza_Sobrinho F., \&. deCarvalho, C.A.B. (2011). The growth dynamics in Brachiaria species according to nitrogen dose and shade. Revista Brasileira de Zootecnia, 40(2), 270-276. https://doi.org/10.1590/S1516-35982011000200006

Permanasari, I., \& Kastono, D. (2012). Pertumbuhan tumpangsari jagung dan kedelai pada perbedaan waktu tanam dan pemangkasan jagung. Jurnal Agroteknologi, 3(1), 13-20. http://dx.doi.org/10.24014/ja.v3i1.90

Rahmasari, D. A., Sudiarso \& Sebayang, H. T. (2016). Pengaruh jarak tanam dan waktu tanam kedelai terhadap pertumbuhan dan hasil tanaman kedelai (Glycine max) pada baris antar tebu (Saccharum officinarum L.). Jurnal Produksi Tanaman, 4(5), 392-398.

Sari, L. A. (2019). Pertumbuhan dan hasil jagung dan kacang tunggak dalam sistem tumpangsari. Jurnal Pertanian, 10(2), 93-116.

Souza, R., Teixeira, I., Reis, E., \& Silva, A. (2016). Soybean morphophysiology and yield response to seeding systems and plant populations. Chilean journal of agricultural research, 76(1), 3-8. http://dx.doi.org/10.4067/S071858392016000100001

Tirta, F. A., Indradewa, D., \& Ambarwati, E. (2017). Pertumbuhan dan hasil sembilan kultivar kedelai (Glycine max (L.) Merrill) yang ditanam bersamaan dengan jagung (Zea mays L.) dalam satu lubang tanam. Vegetalika, 6(1), 22-34. https://doi.org/10.22146/veg.25982

Wardhana, S., Mawarni, L., \& Barus, A. (2014). Kajian penanaman kedelai di bawah kelapa sawit umur empat tahun di PTPN III Kebun Rambutan. Jurnal Agroekoteknologi Universitas Sumatera Utara, 2(3), $1037-1042$. https://dx.doi.org/10.32734/jaet.v2i3.7457

Widyaningrum, I., Nugroho, A,. \& Suwasono_Heddy, Y. B. (2018). Pengaruh jarak tanam dan varietas kedelai terhadap pertumbuhan dan hasil tanaman kedelai (Glycine max L.). Jurnal Produksi Tanaman, 6(8), 1796-1802.

WU, Y. S., Yang, F., Gong, W. Z, Ahmed, S., Fan, Y. F.,Wu, X. L., Yong, T. W., Liu, W. G., Shu, K., Liu, J., Du, J. B., \&Yang, W. Y. (2017). Shade adaptive response and yield analysis of different soybean genotypes in relay intercropping systems. Journal of Integrative Agriculture, 16(6), 1331-1340. https://doi.org/10.1016/S2095-3119(16)61525-3

Yamaji, Naoki, \& Ma, J. F. (2007). Spatial distribution and temporal variation of the rice silicon transporter LSI1. Plant Physiology, 143(3), 1306-1313. https://doi.org/10.1104/pp.106.093005

Yuwariah, Y., Ruswandi, D., \& Irwan, A. W. (2017). Pengaruh pola tanam tumpangsari jagung dan kedelai terhadap pertumbuhan dan hasil jagung hibrida dan evaluasi tumpangsari di Arjasari Kabupaten Bandung. Jurnal Kultivasi, 16(3), 514-521. https://doi.org/10.24198/kultivasi.v16i3.14377 